\title{
Application of Innovative Company Valuation Methods in Latvia: Analysis and Possibilities for Improvement
}

\begin{abstract}
The paper analyses the traditional company valuation methods, as well as the value added intellectual coefficient and its possible use in company valuation. The author evaluates the relationship between intellectual capital and company performance, and proposes a combined corporate valuation model.
\end{abstract}

Keywords: company value, intellectual capital, return on invested capital (ROIC), value added intellectual coefficient (VAIC ${ }^{\text {TM }}$ ).

Straipsnyje analizuojami tradiciniai ịmonès vertinimo metodai, kaip vertę naudojant intelektinị koeficientą ir galimus jo panaudojimo būdus ịmonès vertinime. Autorius vertina ryšị tarp intelektinio kapitalo ir ịmonès veiklos, ir siūlo kompleksinị korporatyvinį vertinimo modelį.

Raktiniai žodžiai: įmonès vertè, intelektinis kapitalas, investuoto kapitalo grąža (ROIC), pridètinès vertès intelektinis koeficientas (VAIC ${ }^{\mathrm{TM}}$ ).

\section{Introduction}

One of the main objectives of company manager is to maximize company value. Company value is at the center of corporate finance, however, finding a value for a company is not easy. First, different companies should be valued differently (for example, public company vs. private company, company in distress, etc.). Second, company value depends on the aim of the valuation as well (one company can have several values, depending on the method). The last two decades have seen a stream of innovation in financial markets, yet corporate valuation methods have not changed significantly. Traditional corporate valuation methods include discounted cash flow valuation, liquidation and accounting valuation, relative valuation and contingent claim valuation (different authors propose various groupings of valuation methods). The bulk of these methods reflect historical performance, while it is necessary to also take into consideration the value which is off-balance-sheet and possible growth.

Traditional corporate valuation methods are based on balance sheet, income statement or cash flow statement; 
however, intellectual capital (IC) is an asset as well. Yet it is valued at zero on the balance sheet. Big differences exist between company market and book value, and a part of it can be explained by IC. Even though there is no universal definition of IC, its information provides an indication about the future potential of a company.

The aim of the study is to investigate the traditional company valuation methods, as well as the value added intellectual coefficient (VAIC ${ }^{\mathrm{TM}}$ ), evaluate the relationship between intellectual capital and company value and propose recommendations for improvement of traditional corporate valuation methods.

The tasks of the research are as follows:

- to overview the traditional company valuation methods;

- to analyse the significance of intellectual capital and review the results of previous research on $\mathrm{VAIC}^{\mathrm{TM}}$;

- to evaluate the relationship between VAIC ${ }^{\mathrm{TM}}$, its components and company value, value creation and return on invested capital (ROIC);

- to make conclusions and work out recommendations for improvement of traditional corporate valuation methods.

The analysis is conducted on sample of 31 Latvian listed companies (Baltic Stock Exchange) over the period from 2005 to 2011. In the research paper, the following qualitative and quantitative methods of research are applied: the monographic method, graphical method, descriptive statistics and correlation analysis. The research is based on published papers on company valuation methods and VAIC ${ }^{\mathrm{TM}}$, as well as the information provided by the Baltic Stock Exchange.

\section{Company valuation methods: an overview}

Maximizing company value and shareholder wealth is increasingly the most important task facing today's managers (Frykman, Tolleryd, 2010). As pointed out by P. Fernandez (2002): "Generally speaking, a company's value is different for different buyers and it may also be different for the buyer and the seller". In addition, value should not be confused with price, which is the quantity agreed between the seller and the buyer in the sale of a company.

Different authors distinguish various aims of the valuation and classification of valuation methods. For example, D. Frykman and J. Tolleryd (2010) point out four situations when it is necessary to value the company: raising capital for growth, creating an incentive programme to keep and attract employees, executing a merger, acquisition or divestiture and conducting and IPO (initial public offering). However, P. Fernandez (2002) distinguishes more uses of company valuation:

- In company buying and selling operations;

- Valuations of listed companies;

- Public offerings;

- Inheritances and wills;

- Compensation schemes based on value creation;

- Identification of value drivers;

- Strategic decisions on the company's continued existence;

- Strategic planning.

D. Frykman and J. Tolleryd (2010) classify corporate valuation models depending on the valuation basis (cash flow, return / earnings, assets) and valuation approach (fundamental, relative) (Table 1). 
Overview of the corporate valuation models: valuation approach

Table 1

\begin{tabular}{|c|c|c|c|c|}
\hline \multirow{4}{*}{$\begin{array}{l}\text { Valuation } \\
\text { approach }\end{array}$} & \multicolumn{4}{|c|}{ Valuation basis } \\
\hline & & Cash flow & Returns / earnings & Assets \\
\hline & Fundamental & $\begin{array}{l}\text { Discounted cash flow, cash flow } \\
\text { return on investment, real options, } \\
\text { dividend discount model }\end{array}$ & $\begin{array}{l}\text { Economic value added, } \\
\text { residual income }\end{array}$ & $\begin{array}{l}\text { Net asset } \\
\text { valuation }\end{array}$ \\
\hline & Relative & $\begin{array}{c}\text { EV / EBITDA, EV / EBIT, } \\
\text { EV / FCF }\end{array}$ & Price / earnings, PEG & $\mathrm{P} / \mathrm{B}$ \\
\hline
\end{tabular}

EV - enterprise value; EBITDA - earnings before interest, taxes, depreciation and amortization; EBIT - earnings before interest and taxes; FCF - free cash flow; PEG - price / earnings to growth ratio; P / B - price-to-book ratio.

Source: Frykman, Tolleryd (2010).

P. Fernandez (2002) classifies the methods for valuing companies in six groups (Table 2) and also states that cash flow discounting methods are becoming increasingly popular and are conceptually "correct".

In addition, many studies examine empirical data in order to find any relationships between value and other indicators of company's performance. For example, A. Gregoriou (2010) found a positive and significant association between market value, book value, earnings, and dividends.

Many studies are done on Economic Value Added (EVA). In particular, from 2000 to 2008 , there has been a remarkable increase in research on EVA and empirical research methodology alone accounted for 71 percent among all four methodologies (empirical, conceptual, descriptive and exploratory cross-sectional) (Sharma, Kumar, 2010). J. A. Abate et al. (2004) stated that the EVA style of investing emphasizes the fundamentals of wealth creation in the profiling of a company and its stock. This can be used to aid investors in their decision to allocate funds between an actively managed and passive indexing approach depending on the degree of capital market efficiency. The study by J. De Wet (2005) has reaffirmed the importance of cash flow management and merits some caution in focusing only on EVA as the measure of

Overview of the corporate valuation models: valuation basis

Table 2

\begin{tabular}{|c|c|c|c|c|c|}
\hline \multicolumn{6}{|c|}{ Main valuation methods } \\
\hline Balance sheet & $\begin{array}{c}\text { Income } \\
\text { statement }\end{array}$ & $\begin{array}{c}\text { Mixed } \\
\text { (goodwill) }\end{array}$ & $\begin{array}{l}\text { Cash flow } \\
\text { discounting }\end{array}$ & $\begin{array}{c}\text { Value } \\
\text { Creation }\end{array}$ & Options \\
\hline $\begin{array}{c}\text { Book value } \\
\text { Adjusted book } \\
\text { value } \\
\text { Liquidation value } \\
\text { Substantial value }\end{array}$ & $\begin{array}{c}\text { Multiples } \\
\text { PER } \\
\text { Sales } \\
\text { P / EBITDA } \\
\text { Other multiples }\end{array}$ & \begin{tabular}{|c|} 
Classic \\
Union of Euro- \\
pean Accounting \\
Experts Abbrevi- \\
ated income \\
Others
\end{tabular} & $\begin{array}{l}\text { Equity cash flow } \\
\text { Dividends } \\
\text { Free cash flow } \\
\text { Capital cash flow } \\
\text { APV }\end{array}$ & $\begin{array}{c}\text { EVA } \\
\text { Economic } \\
\text { profit } \\
\text { Cash value } \\
\text { added } \\
\text { CFROI }\end{array}$ & $\begin{array}{c}\text { Black and Scholes } \\
\text { Investment option } \\
\text { Expand the project } \\
\text { Delay in } \\
\text { investment } \\
\text { Alternative uses }\end{array}$ \\
\hline
\end{tabular}

PER - the share's price divided by the earnings per share; APV - adjusted present value; CFROI - cash flow return on investment; EVA - Economic Value Added.

Source: Fernandez (2002). 
choice for internal company performance. Results by G. W. Kim (2006) do not support the hypothesis that EVA is superior to traditional accounting measures in association with market value of equity. A. P. Dumitru and C. E. Dumitru (2008) also emphasized that several studies show a positive stronger correlation between EVA and MVA (market value added) than the other accounting measures, but the other studies indicate that EVA does not explain MVA better than other measures.

Recently several studies attempt to integrate several approaches, for example, A. Destri et al. (2012) propose a performance and cost measurement system that integrates the Economic Value Added (EVA) firm-wide financial performance measure with the Process Based Costing (PBC) method.

To sum up, many corporate valuation methods exist. Nevertheless, studies find contradictory results, and the corporate finance community is not even close to a universal methodology of company valuation. As emphasized by B. Ryan (2007), valuation is an inexact science at best. Different methods have different advantages in different situations, and some capture important aspects in valuing a business, which are not recognized by others.

Traditional company valuation methods pay more attention to either historical figures (based on the balance sheet, income or cash flow statement) or inexact forecasting (for example, free cash flow and weighted average cost of capital (WACC) for subsequent periods). These methods are mostly taking into consideration the physical assets of the company, while in the knowledge-based economy more emphasis is put on employees and IC. Therefore, afore mentioned corporate valuation methods are not suitable in today's world.

\section{Intellectual capital and its role in corporate valuation}

In a knowledge-based economy, one must take into consideration not only the traditional ways to measure the company value, but it is necessary to recognize IC as well. Traditional measures of a company's performance, which are based on conventional accounting principles, may be unsuitable in the knowledge-based economy which is driven by IC (Gan, Saleh, 2008). As emphasized by J. Wang (2008), investors have to consider intangible assets, such as the human resources, skills, knowledge, processes, and innovation capabilities of an organization. Although IC and knowledge assets are difficult to discern and quantify, their results will nonetheless be reflected in the company's greater productivity, efficiency, and overall profitability. The limitations of financial statements in explaining firm value underline the fact that the source of economic value is no longer the production of material goods, but the creation of IC (Chen et al., 2005).

Intellectual capital is intangible and cannot be accurately measured. For example, D. Frykman and J. Tolleryd (2010) define intellectual capital as all non-financial assets of a company that are not reflected in the balance sheet. Yet N. Tawy and T. Tollington (2012) have observed that there is not universal definition for IC and the cause and effect relationship between IC and value creation is, at best, indirect.

C. Tseng and J. G. Yeong-Jia (2005) concluded that intellectual capital has five characteristics:

- Intangible. Intellectual capital is invisible and intangible, and thus traditional measures do not capture it accurately; 
- Effect of time delays. The effects of heavy investments in human and innovation capital take time to be fully implemented and felt;

- Non-zero-sum effect. Unlike traditional assets represented in accounting and cash flow, intellectual capital flows are not necessarily added to zero;

- Rule of multiplication. Physical asset is measured using an addition rule in traditional financial statements, but intellectual capital is measured as a multiplication rule in a knowledge-based economy;

- Law of increasing return. While land, capital and labor all follow the laws of decreasing return, knowledge and information conversely enjoy increasing return.

Figure 1 represents the intellectual capital value tree.

Components of IC:

- Human capital is the intellectual resources possessed by the individuals in the company and that leaves the company every evening when the employees leave the office;

- Customer capital is defined as the value of all of the relationships the company has with its customers;

- Process capital is all support systems, process documentation, manuals, IT systems and the like;

- Innovation capital consists mainly of brands, patents and documented ideas.

Value Added Intellectual Coefficient (VAIC ${ }^{\mathrm{TM}}$ ) is a method developed by A. Pulic, which monitors and measures the value creation efficiency in the company according to accounting based figures (Pulic, 2000). The VAIC ${ }^{\mathrm{TM}}$ model (Figure 2) is intended to measure the extent to which a company produces added value based on intellectual (capital) efficiency or intellectual resources (Stahle et al., 2011).

A. Riahi-Belkaoui (2003) defines value added (VA) as:

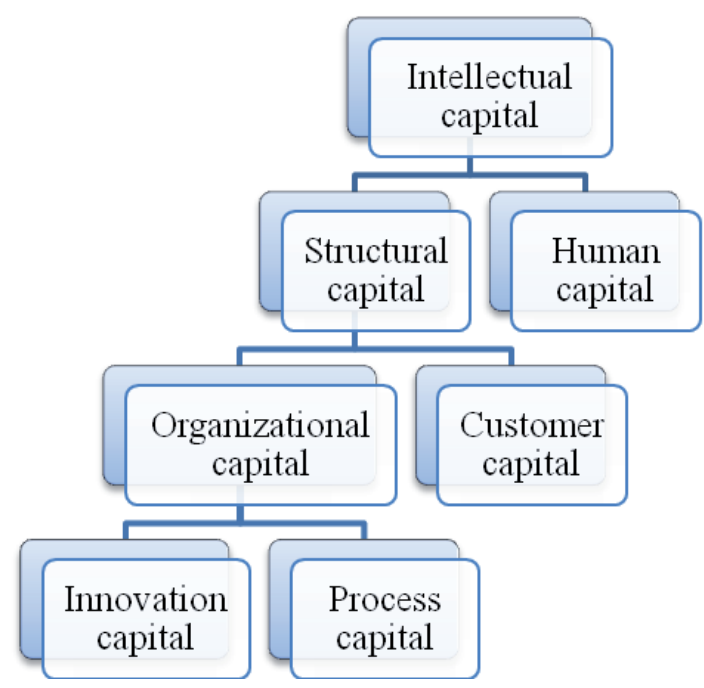

Fig. 1. The intellectual capital value tree

Source: Frykman, Tolleryd (2010). 


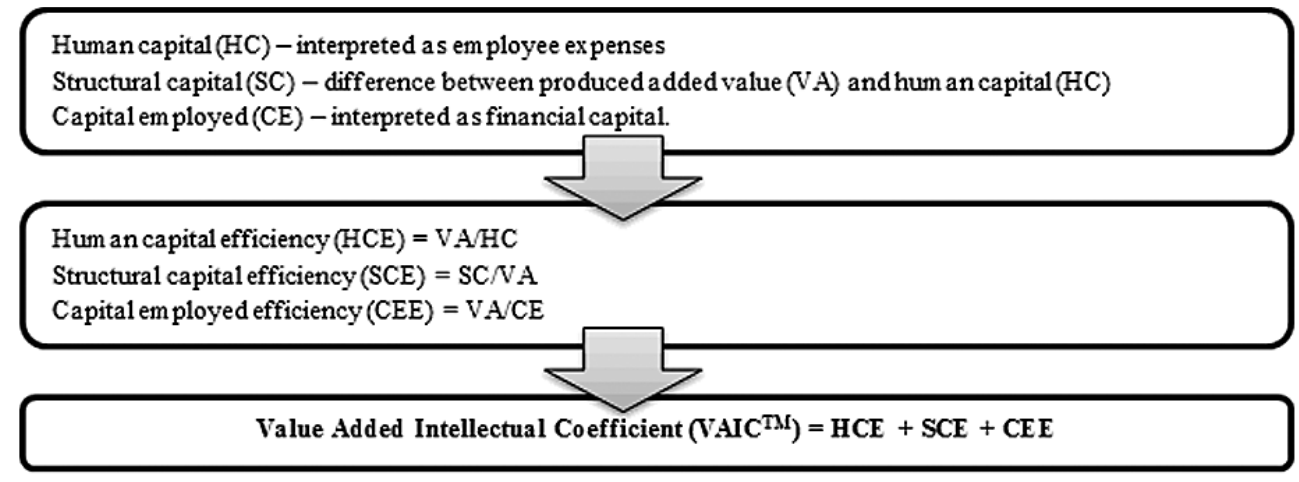

Fig. 2. The composition of VAIC ${ }^{\text {TM }}$

$$
\mathrm{VA}=\mathrm{W}+\mathrm{I}+\mathrm{DD}+\mathrm{T}+\mathrm{R},
$$

where $\mathrm{W}$ is wages, $\mathrm{I}$ - interest, $\mathrm{DD}$ dividends, $\mathrm{T}$ - taxes and $\mathrm{R}$ - net income.

VAIC $^{\mathrm{TM}}$ measures how much new value has been created per invested monetary unit of resources. A high coefficient indicates a higher value creation using company's resources. Capital employed efficiency (CEE) shows how much new value has been created by one unit of investment in the capital employed. Human capital efficiency (HCE) indicates how much value added has been created by one financial unit invested in the employees. Structural capital efficiency (SCE) is the indicator of the VA efficiency of structural capital (Gan, Saleh, 2008).

S. Firer and M. Williams (2003) emphasized two advantages of VAIC ${ }^{\mathrm{TM}}$ :

a) An easy-to-calculate, standardized, and consistent basis of measure, enabling effective comparative analyses across firms and countries;

b) Data used in the calculation of VAIC $^{\mathrm{TM}}$ are based on financial statements, which are usually audited by professional public accountants.
Many papers are published on IC or $\mathrm{VAIC}^{\mathrm{TM}}$ and company performance. H. Shiu (2006) found that VAIC ${ }^{\mathrm{TM}}$ has a positive correlation with profitability (ROA) and market valuation (market-tobook ratio), while a negative correlation with productivity was found. The study by J. Wang (2008) is the first to apply multiregression models to examine value relevance of valuation methods of IC, and the results show that Tobin's Q, KCE (Knowledge Capital Earnings), and VAIC ${ }^{\text {TM }}$ have a positive relationship with company value. The results by Chen et al. (2005) provide empirical evidence that investors place higher value on firms with better IC efficiency, and that company with better intellectual efficiency gains greater profitability and revenue growth in both the current and the following years.

In addition, some authors have critically evaluated the use and application of VAIC ${ }^{\mathrm{TM}}$. The analysis by P. Stahle et al. (2011) shows that VAIC ${ }^{\mathrm{TM}}$ parameters have nothing to do with IC; they merely indicate the efficiency of the company's labor and capital investments. The study by D. Maditinos et al. (2011) indicates a significant relationship between human capital efficiency and the return on equity. 
In addition, it was emphasized that despite the fact that IC is increasingly recognized as an important strategic asset for sustainable corporate competitive advantages, the results give rise to various arguments, criticism and further research on the subject. The results obtained by G. Mehralian et al. (2012) using correlation and multiple regression analysis failed to support the impact of IC on market value. O. Ferraro and S. Veltri (2011) also found that the IC variables do not have a meaningful relation with the market value.

Some studies found no relationship between IC, VAIC ${ }^{\mathrm{TM}}$ and company performance, yet components of VAIC ${ }^{\mathrm{TM}}$ show different results. The empirical study by Chu et al. (2010) examined the IC and its association with business performance. Using regression analysis, no conclusive evidence was found to support the associations between $\mathrm{VAIC}^{\mathrm{TM}}$ as an aggregate measure and the four financial indicators (market-to-book value, return on assets, asset turnover and return on equity). However, a component of VAIC ${ }^{\mathrm{TM}}$ was found to predict a substantial variance in business performance. K. Kin and Z. Saleh (2008) used correlation and regression models to examine the relationship between corporate value creation efficiency and firms' market valuation, profitability and productivity. The study found that individually each component of the VAIC $^{\mathrm{TM}}$ provides different values compared to the aggregate measure, which implies that investors place different value on the three VAIC $^{\mathrm{TM}}$ components. In addition, VAIC ${ }^{\mathrm{TM}}$ can explain profitability and productivity, but fails to explain market valuation.

Some studies were published on Baltic companies. For example, I. Macerinskiene and S. Survilaite (2011) carried out a survey, where respondents were asked to assign a score to different resources in the Likert scale from 1 to 7 . Financial resources in Lithuanian companies are the most important resources today (mean - 6), while human resources are in the second place (mean - 5.07).

As emphasized by A. Volkov (2012), there is a potential for a diversity of uses in the application of $\mathrm{VAIC}^{\mathrm{TM}}$. Undeniable is the fact that IC is an asset of the company and an increase in IC should increase the value of the company as well. Yet empirical results of IC and VAIC ${ }^{\mathrm{TM}}$ are inconsistent. Some studies find positive correlation between IC and company value, while others do not find any relationship. In addition, there is a bulk of studies, which find a connection between VAIC ${ }^{\mathrm{TM}}$ components and market value. Certainly the subject of IC and its impact on value is topical and more research is necessary.

\section{Return on invested capital, value creation and Tobin's Q}

In order to perform an analysis between IC and company performance, several indicators were selected - return on invested capital (ROIC), value added and Tobin's Q.

Company value is created if ROIC exceeds the cost of capital over time (Figure 3).

The return on capital or invested capital in a business attempts to measure the return earned on capital invested in an investment (Damodaran, 2007):

Return on Invested Capital $($ ROIC $)=$ $\frac{\text { Operating } \text { Income }_{t}(1-\text { tax rate })}{\text { Book Value of Invested Capital }}$ 


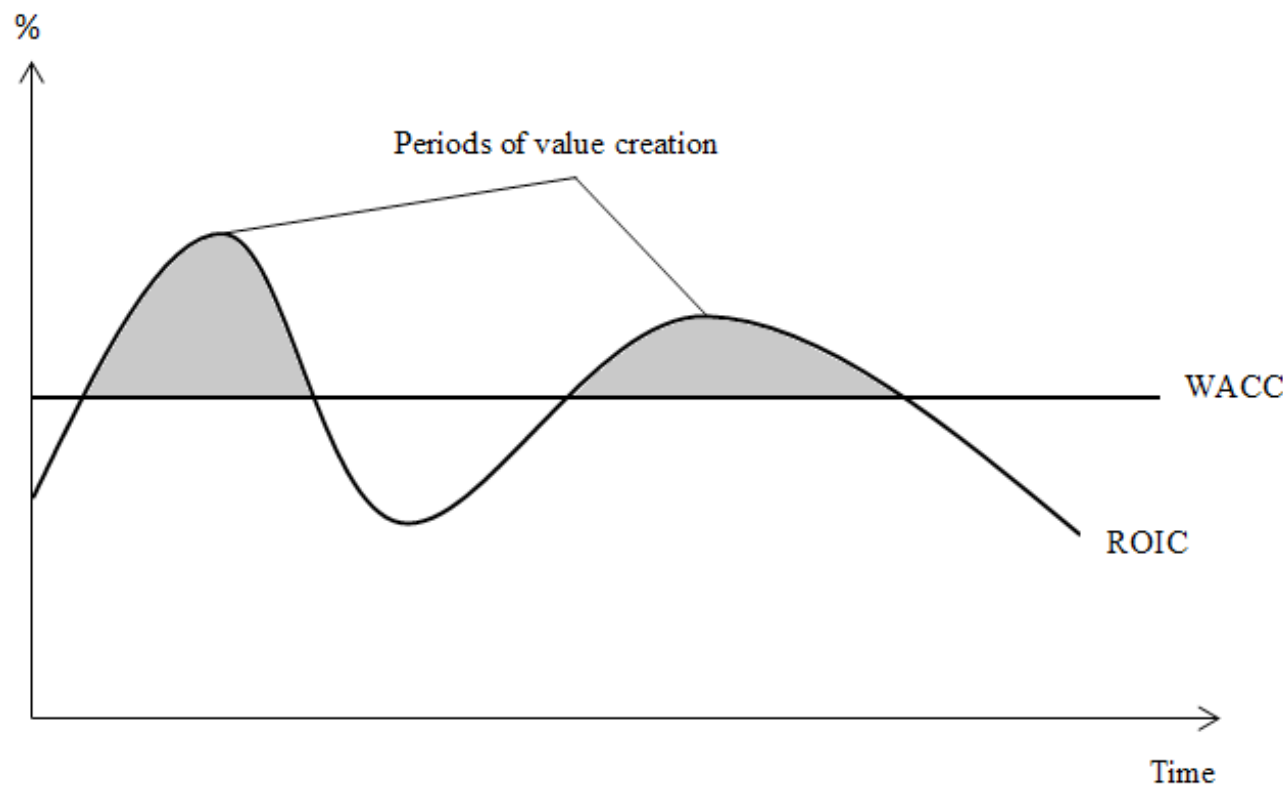

Fig. 3. Relationship between cost of capital, ROIC and value creation

Source: Frykman, Tolleryd (2010).

Weighted-average cost of capital (WACC) is calculated using the methodology by I. Berzkalne and E. Zelgalve (2011):

$$
\begin{aligned}
& W A C C=r_{\theta}+r_{i}+r_{a}=\frac{D_{0}}{A_{k} K}+\left(r_{f}+\frac{r_{m}+r_{a}}{2}\right)+ \\
& \left(r *(1-t)+\frac{\text { capital costs }}{\text { capital raised }} * 100\right)
\end{aligned}
$$

where $r_{e}-$ cost of equity, $r_{i}-$ cost of retained earnings, $\mathrm{r}_{\mathrm{a}}$ - cost of debt, $\mathrm{D}_{0}$ dividend paid in the reference year, $\mathrm{A}_{\mathrm{k}} \mathrm{K}$ share capital (paid), $\mathrm{r}_{\mathrm{f}}$ - return on a riskfree assets, $r_{m}$ - average return of the stock market, $\mathrm{r}$ - nominal interest rate, $\mathrm{t}$ - rate of corporate income tax.

As a proxy for company value used Tobin's Q, which was introduced by James Tobin (1969). There are several methodologies and formulas used in the calculation of Tobin's Q (for example, see Wernerfelt, Montgomery, 1998; Linderberg, Ross,
1981; Chung, Pruitt, 1994). This study uses the methodology by Y. Jin and P. Jorion (2006). This methodology was used, for example, by J. E. Gomez-Gonzales et al. (2012).

Tobin's $q=\frac{B V \text { total assets }}{B V \text { total assets }}-$

BV common equity $+M V$ common equity

BV total assets

where $\mathrm{BV}$ is book value and $\mathrm{MV}$ is market value.

If Tobin's $\mathrm{Q}$ is greater than 1 , then the market value is greater than the book value of the assets of the company; the market may be overvaluing the company. On the other hand, if Tobin's Q less than 1, then the market value is less than the book value of the assets of the company; the market may be undervaluing the company. 
Figure 4 represents the average Tobin's Q for each year for companies of Main list and Secondary list. As can be seen, Tobin's Q decreased significantly for the Main list companies in 2009 (compared to previous years), however recently it has increased again and in 2011 it was above 1 . A different situation can be found for the companies of Secondary list. The Tobin's Q has never exceeded 1; the highest value was achieved in 2007 (0.91). Overall, these results indicate that the market might be undervaluing the companies of Secondary list, while overvaluing the companies of Main list.

\section{Empirical analysis and discussion of results}

Table 3 presents mean indicators of all variables included in the study, separate calculation was done for Main list and Secondary list. A VAIC ${ }^{\mathrm{TM}}$ of 2.98 was obtained, indicating that the company created LVL 2.98 out of every LVL 1.00 invested in the company. This indicator is slightly higher for the Main list (3.08) than for the Secondary list (2.97). If the components are examined individually, then one can conclude that human capital

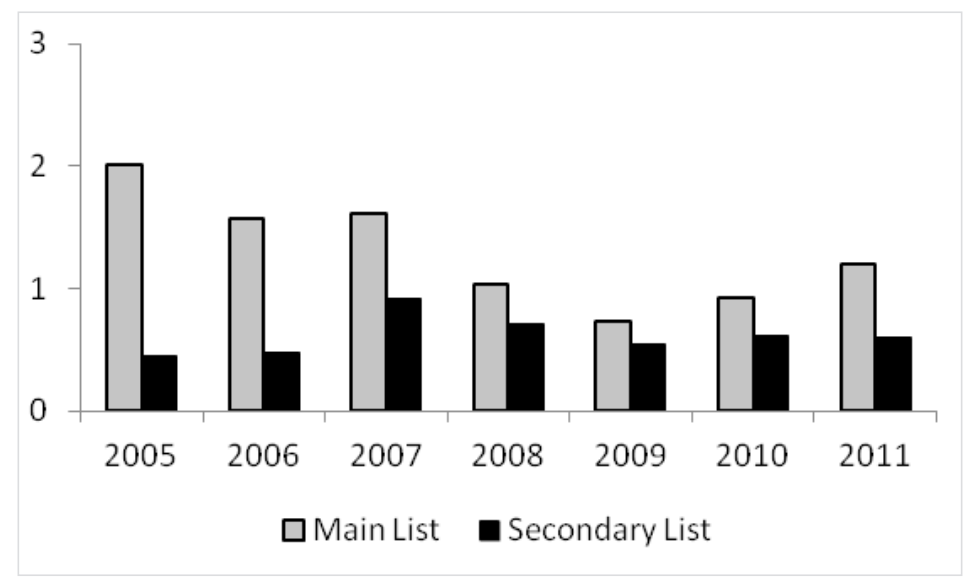

Fig. 4. Average Tobin's Q for companies of Main List and Secondary List, 2005-2011

Source: prepared by the author of the paper.

Mean indicators of variables included in the study, 2005-2011

\begin{tabular}{|l|c|c|c|}
\hline & All companies & Main Llist & Secondary List \\
\hline Tobin's Q & 0.73 & 1.30 & 0.62 \\
\hline ROIC, \% & 10.6 & 12.5 & 10.2 \\
\hline Value added, \% & -4.6 & -0.64 & -5.4 \\
\hline Capital employed efficiency (CEE) & 0.38 & 0.44 & 0.36 \\
\hline Human capital efficiency (HCE) & 2.02 & 1.95 & 2.04 \\
\hline Structural capital efficiency (SCE) & 0.58 & 0.69 & 0.56 \\
\hline VAIC $^{\text {TM }}$ & 2.98 & 3.08 & 2.97 \\
\hline
\end{tabular}

Source: author's calculations based on the annual reports of the listed companies. 
(mean $=2.02)$ is more efficient in comparison to capital (mean $=0.38$ ).

Based on the previously mentioned methodology, ROIC, WACC and the net result $($ ROIC - WACC $=$ value added $)$ were calculated for Main list (Figure 5) and Secondary list (Figure 6) companies.

If ROIC exceeds WACC, then value is added, and vice versa. From 2005 to 2008, ROIC exceeded WACC for the companies of Main list, therefore, value was created. Due to the financial crisis, a significant drop can be seen in 2009 and subsequently in 2010 (decrease in value), while in 2011 ROIC equaled WACC for the companies of Main list.

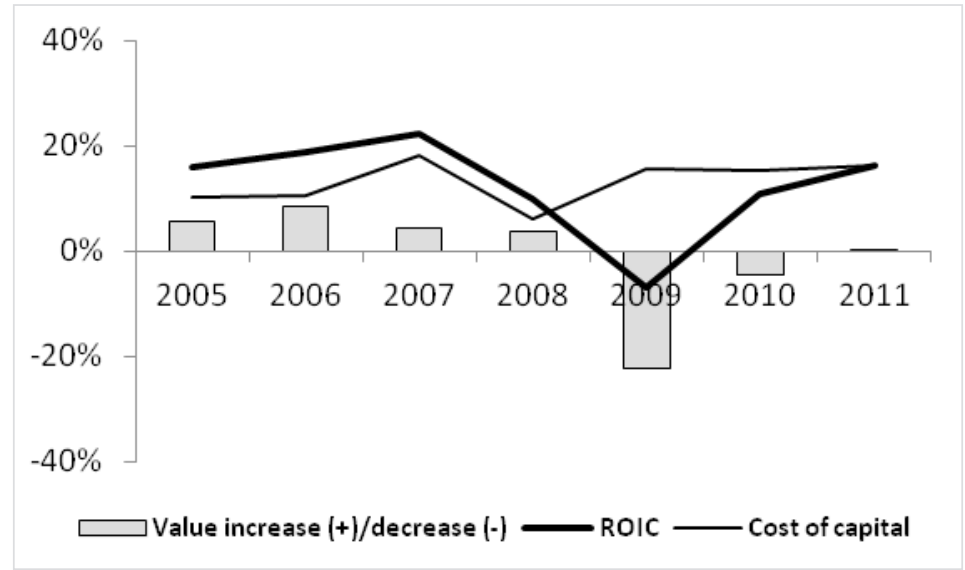

Fig. 5. ROIC, WACC and value added for Latvian listed companies (Main List), 2005-2011

Source: prepared by the author of the paper.

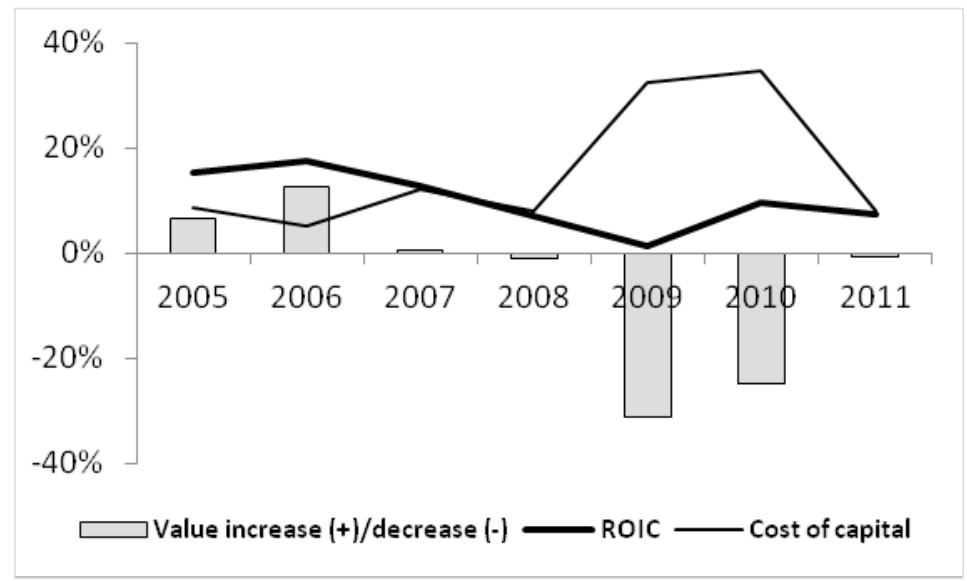

Fig. 6. ROIC, WACC and value added for Latvian listed companies (Secondary List), 2005-2011 
A different situation can be observed for the companies of Secondary list. WACC exceeded ROIC already in 2008 and the decrease in value in 2009 was more significant $(31 \%)$ than for the companies of Main list (22\%). In addition, WACC of the Secondary list companies in 2009-2010 increased to a greater extent compared to Main list. This might mean that investors regard these companies as more risky.

Figure 7 shows the average value added intellectual coefficient (VAIC ${ }^{\mathrm{TM}}$ ) for companies of Main list and Secondary list.

All coefficients exceed 1 and it means that an average company created more than LVL 1 out of every LVL 1 invested in the company. The highest return was achieved in 2007 for companies of the Main list (companies on average created LVL 4.58 out of every LVL 1.00). On the other hand, one must note, that the results of the Main list are more volatile if compared to the Secondary list. No significant differences can be found if one compares the proportion of VAIC ${ }^{\mathrm{TM}}$ components for companies of Main list and Secondary list
(Figure 8 and 9). In 2010, Human capital efficiency (HCE) component decreased significantly for Main list companies. However it is necessary to note that, in the Main list, there are only 5 companies and in this year two out of these five companies reported significant loses.

Finally, correlation method is applied. The Pearson correlation ratio measures the degree and direction of linear relationship between two variables. Correlation coefficient of +1 corresponds to a perfect linear relationship, coefficient of -1 corresponds to a perfect negative linear relationship, and 0 indicates no linear relationship.

Table 4 provides the Pearson correlation matrix of the variables included in the study:

- VAIC $^{\mathrm{TM}}$ is positively correlated with ROIC, CEE, HCE and SCE. Positive correlation between VAIC ${ }^{\mathrm{TM}}$, CEE, HCE and SCE is expected, since VAIC ${ }^{\mathrm{TM}}$ is calculated as the sum of CEE, HCE and SCE. A strong relationship (correlation coefficient of 0.78 ) indicates that an increase in VAIC $^{\mathrm{TM}}$ is associated with an increase in ROIC as well;

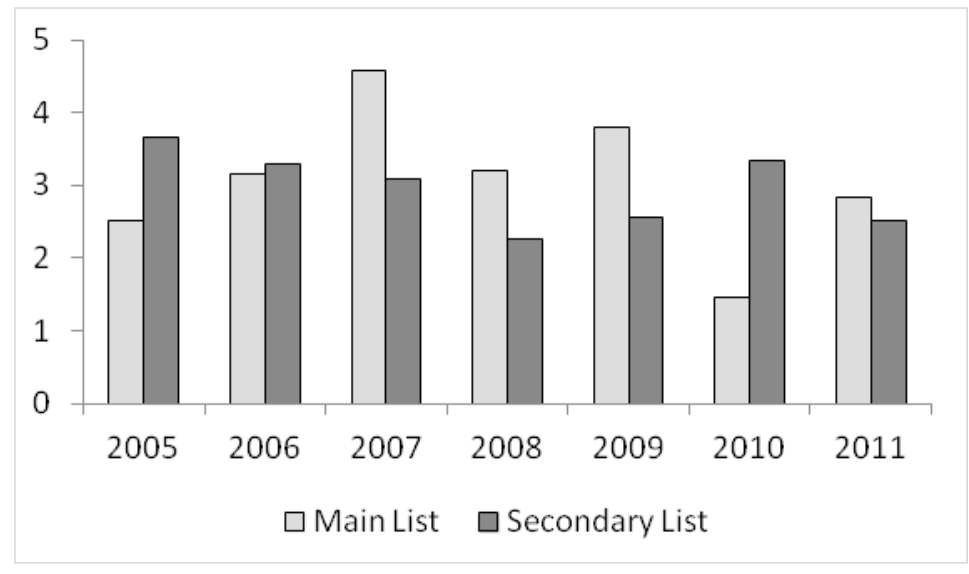

Fig. 7. Average VAIC'M for Latvian listed companies, 2005-2011

Source: prepared by the author of the paper. 


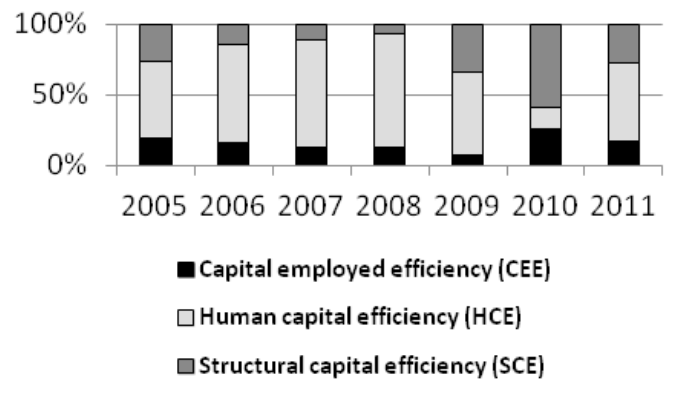

Fig. 8. VAIC ${ }^{\mathrm{TM}}$ components for Latvian listed companies (Main List), 2005-2011

Source: prepared by the author of the paper.

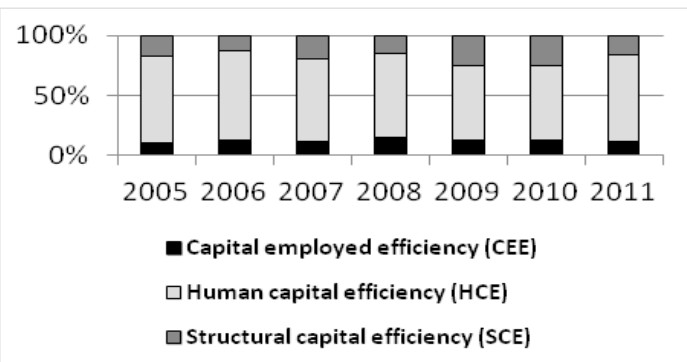

Fig. 9. VAIC ${ }^{\text {TM }}$ components for Latvian listed companies (Secondary List), 2005-2011

Source: prepared by the author of the paper.

Pearson correlation matrix for Latvian listed companies, 2005-2011

\begin{tabular}{|c|c|c|c|c|c|c|c|}
\hline & Tobin's Q & ROIC & Value added & CEE & HCE & SCE & VAIC $^{\mathrm{TM}}$ \\
\hline Tobin's Q & 1 & & & & & & \\
\hline ROIC & $\begin{array}{l}0.267^{* *} \\
(0.000)\end{array}$ & 1 & & & & & \\
\hline Value added & \begin{tabular}{|l|}
-0.061 \\
$(0.391)$ \\
\end{tabular} & \begin{tabular}{|l|}
-0.088 \\
$(0.212)$ \\
\end{tabular} & 1 & & & & \\
\hline CEE & $\begin{array}{l}0.356^{* *} \\
(0.000)\end{array}$ & $\begin{array}{l}0.884^{* *} \\
(0.000)\end{array}$ & $\begin{array}{l}-0.402^{\star *} \\
(0.000)\end{array}$ & 1 & & & \\
\hline HCE & \begin{tabular}{|l}
$0.201^{\star *}$ \\
$(0.004)$
\end{tabular} & $\begin{array}{l}0.781^{\star \star} \\
(0.000) \\
\end{array}$ & $\begin{array}{l}-0.164^{*} \\
(0.019) \\
\end{array}$ & $\begin{array}{l}0.721^{\star *} \\
(0.000)\end{array}$ & 1 & & \\
\hline SCE & \begin{tabular}{|l|}
-0.041 \\
$(0.564)$
\end{tabular} & \begin{tabular}{|l|}
-0.058 \\
$(0.408)$
\end{tabular} & $\begin{array}{l}-0.071 \\
(0.315)\end{array}$ & $\begin{array}{l}-0.040 \\
(0.571)\end{array}$ & \begin{tabular}{|l|}
-0.068 \\
$(0.332)$ \\
\end{tabular} & 1 & \\
\hline VAIC $^{\text {TM }}$ & $\begin{array}{l}0.216^{\star *} \\
(0.002)\end{array}$ & $\begin{array}{l}0.781^{\star *} \\
(0.000)\end{array}$ & $\begin{array}{l}-0.234^{* *} \\
(0.001) \\
\end{array}$ & $\begin{array}{l}0.761^{\star *} \\
(0.000)\end{array}$ & $\begin{array}{l}0.926^{\star *} \\
(0.000)\end{array}$ & $\begin{array}{l}0.291^{\star *} \\
(0.000)\end{array}$ & 1 \\
\hline
\end{tabular}

** Correlation is significant at the 0.01 level (2-tailed), ${ }^{*}$ Correlation is significant at the 0.05 level (2-tailed).

Source: author's calculations based on the annual reports of the listed companies. 
- There is a strong positive relationship between CEE, HCE and ROIC as well, while there is no significant correlation between SCE and ROIC;

- Tobin's Q increases with the increase in ROIC, CEE, HCE and VAIC ${ }^{\mathrm{TM}}$.
To sum up, company value and return on invested capital increase with the increase in value creation efficiency.

Correlation results for Main list and Secondary list are included in Table 5 and Table 6, respectively. Several differences can be stated:

Pearson correlation matrix for Latvian listed companies (Main List), 2005-2011

Table 5

\begin{tabular}{|l|c|c|c|c|c|c|c|}
\hline & Tobin's Q & ROIC & Value added & CEE & HCE & SCE & VAIC $^{\text {TM }}$ \\
\hline Tobin's Q & 1 & & & & & & \\
\hline \multirow{2}{*}{ ROIC } & $\begin{array}{l}0.661^{* *} \\
(0.000)\end{array}$ & 1 & & & & & \\
\hline \multirow{2}{*}{ Value added } & $\begin{array}{c}0.575^{* *} \\
(0.000)\end{array}$ & $\begin{array}{c}0.792^{* *} \\
(0.000)\end{array}$ & 1 & & & & \\
\hline \multirow{2}{*}{ CEE } & $\begin{array}{l}0.710^{* *} \\
(0.000)\end{array}$ & $\begin{array}{l}0.913^{* *} \\
(0.000)\end{array}$ & $\begin{array}{c}0.601^{* *} \\
(0.000)\end{array}$ & 1 & & & \\
\hline \multirow{2}{*}{ HCE } & 0.156 & $0.515^{* *}$ & 0.102 & $0.600^{* *}$ & 1 & & \\
\hline \multirow{2}{*}{ SCE } & $(0.371)$ & $(0.002)$ & $(0.560)$ & $(0.000)$ & & & \\
\hline \multirow{2}{*}{ VAIC } & -0.156 & -0.288 & -0.286 & -0.300 & -0.205 & & \\
& $(0.372)$ & $(0.093)$ & $(0.095)$ & $(0.079)$ & $(0.237)$ & 1 & \\
\hline
\end{tabular}

** Correlation is significant at the 0.01 level (2-tailed), *Correlation is significant at the 0.05 level (2-tailed).

Source: author's calculations based on the annual reports of the listed companies.

Table 6

Pearson correlation matrix for Latvian listed companies (Secondary List), 2005-2011

\begin{tabular}{|l|c|c|c|c|c|c|c|}
\hline & Tobin's Q & ROIC & Value added & CEE & HCE & SCE & VAIC $^{\text {TM }}$ \\
\hline Tobin's Q & 1 & & & & & & \\
\hline ROIC & $\begin{array}{l}0.201^{* *} \\
(0.009)\end{array}$ & 1 & & & & & \\
\hline Value added & $\begin{array}{c}-0.134 \\
(0.083)\end{array}$ & $\begin{array}{c}-0.157^{*} \\
(0.042)\end{array}$ & 1 & & & & \\
\hline \multirow{2}{*}{ CEE } & $\begin{array}{l}0.309^{* *} \\
(0.000)\end{array}$ & $\begin{array}{c}0.882^{* *} \\
(0.000)\end{array}$ & $\begin{array}{c}-0.470^{* *} \\
(0.000)\end{array}$ & 1 & & & \\
\hline \multirow{2}{*}{ HCE } & $0.232^{* *}$ & $\begin{array}{c}0.862^{* *} \\
(0.000)\end{array}$ & $\begin{array}{c}-0.209^{* *} \\
(0.007)\end{array}$ & $\begin{array}{c}0.774^{* *} \\
(0.000)\end{array}$ & 1 & & \\
\hline \multirow{2}{*}{ SCE } & $-0.002)$ & -0.036 & -0.061 & -0.020 & -0.047 & & \\
$(0.564)$ & $(0.646)$ & $(0.434)$ & $(0.800)$ & $(0.545)$ & 1 & \\
\hline \multirow{2}{*}{ VAIC TM } & $0.225^{* *}$ & $0.833^{* *}$ & $\begin{array}{c}-0.279^{* *} \\
(0.000)\end{array}$ & $\begin{array}{c}0.794^{* *} \\
(0.000)\end{array}$ & $\begin{array}{c}0.915^{* *} \\
(0.000)\end{array}$ & $\begin{array}{c}0.341^{* *} \\
(0.000)\end{array}$ & 1 \\
\hline
\end{tabular}

** Correlation is significant at the 0.01 level (2-tailed), *Correlation is significant at the 0.05 level (2-tailed).

Source: author's calculations based on the annual reports of the listed companies. 
- The relationship between company value and return on invested capital is stronger for Main list companies than for Secondary list companies (correlation coefficients are 0.66 and 0.20 , respectively);

- Value added is positively and significantly correlated with Tobin's Q, ROIC and CEE for Main list companies, while for Secondary list companies the correlation coefficients are negative;

- VAIC $^{\mathrm{TM}}$ is significantly correlated with all variables included in the study for companies of Secondary list (all correlation coefficients are statistically significant), while in the case of Main list there are three significant correlations - with ROIC, CEE and HCE;

- If one analyzes the components of $\mathrm{VAIC}^{\mathrm{TM}}$, then no significant relationships can be found with SCE (regardless of the list; with the exception of correlation between SCE and VAIC ${ }^{\mathrm{TM}}$ for the companies of the Secondary list).

To sum up, one can find a significant and positive relationship between VAIC $^{\mathrm{TM}}$, company value and ROIC. On the other hand, value added shows mixed results. Value added has a negative relationship with VAIC ${ }^{\mathrm{TM}}$ and its components in the companies of the Secondary list, however, in the case of Main list the correlation between value added and CEE it is significantly positive (correlation coefficient of 0.601).

Value creation efficiency (or its components $\mathrm{CEE}$ and $\mathrm{HCE}$ ) has a positive impact on company value and return on invested capital for the companies of the Main list. Therefore, the author of this paper recommends combining the traditional company valuation methods with VAIC ${ }^{\mathrm{TM}}$ or its components CEE and HCE in order to achieve better company valuation.
The advantages of combined model would be:

- Such a model would not only include historical information (based on the annual report), but also recognize the significance of IC as well;

- Model will be able to help explaining the difference between company's market value and its book value;

- Inclusion of IC and VAIC ${ }^{\mathrm{TM}}$ supplements company valuation model with indication of company's future potential.

Overall, based on the findings, there is a significant positive relationship between IC and company value for the companies of the Main list, therefore, it is only logical that the value of a company should be composed of its tangible assets and IC as well.

\section{Conclusions and recommendations}

The research covered Latvian listed companies for the period of 2005-2011, and analyzed the traditional company valuation methods, as well as emphasized the role of intellectual capital. The study finds that:

1. Traditional company valuation methods take into consideration historical figures or inexact forecasting. In addition, these methods mostly use the physical assets of the company, while in the knowledge-based economy, more emphasis is put on employees and IC, therefore, one can conclude that these methods do not perform adequately anymore and new concepts and methodologies are needed to be worked out;

2. Widely used indicator of IC is VAIC $^{\mathrm{TM}}$ and there is the potential to use this coefficient for improvement of company valuation methods. Yet previous empirical results are inconsistent. Some studies find positive correlation between 
IC and company value, while others do not find any relationship at all. Several studies have observed a connection between VAIC ${ }^{\mathrm{TM}}$ components and company market value;

3. Based on results of VAIC ${ }^{\mathrm{TM}}$, Latvian listed companies, in the period of 20052011, created on average LVL 2.98 out of every LVL 1.00 invested in the company. In addition, human capital ( mean $=2.02$ ) is more efficient in this aspect, when compared to capital (mean $=0.38$ ). The highest return was achieved in 2007 for the companies of Main list (created LVL 4.58 out of every LVL 1.00);

4. From 2005 to 2008 , ROIC exceeded WACC for the companies of Main list, therefore, value was created but due to the financial crisis, a significant drop can be seen in 2009 and subsequently in 2010. Since WACC, in 2009-2010, increased to a greater extent for companies of the Secondary list, one can conclude that investors regard these companies as more risky;

5. Based on the correlation analysis, it was observed that company value and return on invested capital increase with the increase in value creation efficiency. The relationship between company value and return on invested capital is stronger for Main list companies than for Secondary list companies. Value added showed mixed results;

6. VAIC $^{\mathrm{TM}}$ is significantly correlated with all variables included in the study for companies of Secondary list, while in the case of Main list, significant correlations are with return on invested capital, CEE, and HCE. If one analyzes the components of $\mathrm{VAIC}^{\mathrm{TM}}$, then no significant relationships can be found with SCE (with the exception of correlation between SCE and VAIC $^{\mathrm{TM}}$ for the companies of the Secondary list). However, statistically significant correlations exist between HCE, CEE and Tobin's Q, ROIC and value added;

7. The author of this paper recommends combining the traditional company valuation methods with $\mathrm{VAIC}^{\mathrm{TM}}$ or its components CEE and HCE in order to improve the company valuation model. Such a model would be more efficient and achieve better corporate valuation results, since it not only includes historical information from financial reports, but takes into consideration IC as well. Company value should be composed of both its tangible assets and intellectual capital.

\section{References}

1. Abate, J. A., Grant, J. A., Stewart, III B. G. (2004). The EVA Style of Investing // The Journal of Portfolio Management. Vol. 30, Issue 4, p. 61-73. doi: $10.3905 / j p m .2004 .61$.

2. Berzkalne, I., Zelgalve, E. (2011). Application of the Weighted - Average Cost of Capital in Latvia: Analysis, Problems and Possibilities for Improvement // Applied Economics: Systematic Research. Vol. 5, Issue 2, p. 143-161.

3. Chen, M., Cheng, S., Yuchang, H. (2005). An Empirical Investigation of the Relationship between Intellectual Capital and Firms' Market Value and Financial Performance // Journal of
Intellectual Capital. Vol. 6, Issue 2, p. 15-176. doi: 10.1108/14691930510592771.

4. Chu, S. K. W., Chan, K. H., Yu, K. Y., Ng, H. T., Wong, W. K. (2010). An Empirical Study of the Impact of Intellectual Capital on Business Performance // Journal of Information \& Knowledge Management. Vol.10, No.1, p. 11-21. doi: 10.1142/S0219649211002791.

5. Chung, K. H., Pruitt, S. W. (1994). A Simple Approximation of Tobin's q// The Journal of the Financial Management Association. Vol. 23, No. 3, p. 70-74.Internet access: <http://www.jstor.org/ stable/3665623>, [Accessed June 9, 2013]. 
6. Damodaran, A. (2007). Return on Capital (ROC), Return on Invested Capital (ROIC) and Return on Equity (ROE): Measurement and Implications. Internet access: <http://pages.stern. nyu.edu/ adamodar/>, [Accessed May 4, 2013].

7. De Wet, J. (2005). EVA versus Traditional Accounting Measures of Performance as Drivers of Shareholder Value - A Comparative Analysis // Meditari. Vol. 13, No. 2, p. 1-16. doi: 10.1108/10222529200500009.

8. Destri, A., Picone, P., Mina, A. (2012). Bringing Strategy Back into Financial Systems of Performance Measurement: Integrating EVA and PBC // Business Systems Review. Vol. 1, Issue 1, p. 85-102. doi: 10.7350/BSR.A09.2012.

9. Dumitru, A. P., Dumitru, C. E. (2008). EVA versus Traditional Accounting Measures of Performance as Drivers of Shareholder Value A Comparative Analysis. - Paper presented at the 2008 International Conference on Economics, Law and Management, Romania, June 4-7.

10. Fernandez, P. (2002). Company Valuation Methods. The Most Common Errors in Valuations. Internet access: <www.iese.edu/research/pdfs/ di-0449-e.pdf $>$, [Accessed April 30, 2013].

11. Ferraro, O., Veltri, S. (2011). The Value Relevance of Intellectual Capital on the Firm's Market Value: An Empirical Survey on the Italian Listed Firms // International Journal of Knowledge-Based Development. Vol. 2, Issue 1, p. 6684. doi: 10.1504/IJKBD.2011.040626.

12. Firer, S., Williams, M. (2003). Intellectual Capital and Traditional Measures of Corporate Performance // Journal of Intellectual Capital. Vol. 4, No. 3, p. 348-360. doi: 10.1108/14691930310487806.

13. Frykman, D., Tolleryd, J. (2010). Corporate Valuation, $2^{\text {nd }}$ ed.- Prentice Hall: Financial Times Guide.

14. Gan, K., Saleh, Z. (2008). Intellectual Capital and Corporate Performance of TechnologyIntensive Companies: Malaysia Evidence // Asian Journal of Business and Accounting. Vol. 1, Issue 1, p. 113-130. Internet access: <http://umepublication.um.edu.my/filebank/ published_article/404/Vol1(1)-Article6.pdf >, [Accessed June 9, 2013].

15. Gomez-Gonzalez, J. E., Rincon, C. E. L., Rodriguez, K. J. L. (2012). Does the Use of Foreign Currency Derivatives Affect Firm's Market Value? // Evidence from Colombia. Emerging Markets Finance \& Trade. Vol. 48, No. 4, p. 50-66. doi: 10.2753/REE1540-496X480403.

16. Gregoriou, A. (2010). Corporate Valuation and Dividends: UK Evidence from Panel Unit Root and Cointegration Tests // Atlantic Economic Journal. Vol. 38, p. 15-22. doi: 10.1007/s11293009-9203-9.

17. Jin, Y., Jorion, P. (2006). Firm Value and Hedging: Evidence from U.S. Oil and Gas Producers // The Journal of Finance. Vol. 61, No. 2, p. 893919. doi: 10.1111/j.1540-6261.2006.00858.x.

18. Kim, G. W. (2006). EVA and Traditional Accounting Measures: which Metric is a better predictor of Market Value of Hospitality Companies? // Journal of Hospitality \& Tourism Research. Vol. 30, Issue 1, p. 34-49. doi: $10.1177 / 1096348005284268$.

19. Linderberg, E. B., Ross, S. A. (1981). Tobin's $\mathrm{q}$ Ratio and Industrial Organization // Journal of Business. Vol. 54, No. 1, p. 1-32 .doi: $10.2307 / 2352631$.

20. Macerinskiene, I., Survilaite, S. (2011). Intellectual capital as the main factor of company's value added // Intellectual economics. Vol. 5, No. 4 (12), p. 560-574. Internet access: <http:// connection.ebscohost.com/c/articles/73984403/ intellectual-capital-as-main-factor-companysvalue-added $>$, [Accessed June 9, 2013].

21. Maditinos, D., Chatzoudes, D., Tsairidis, C., Theriou, G. (2011). The Impact of Intellectual Capital on Firm's Market Value and Financial Performance // Journal of Intellectual Capital. Vol. 12, Issue 1, p. 132-151. doi: $10.1108 / 14691931111097944$.

22. Mehralian, G., Rasekh, H. R., Akhavan, P., Sadeh, M. R. (2012). The Impact of Intellectual Capital Efficiency on Market Value: An Empirical Study from Iranian PharmaceuticalCompanies//Iranian Journal of Pharmaceutical Research. Vol. 11, Issue 1, p. 195-207. Internet access: <http://connection. ebscohost.com/c/articles/74248916/impactintellectual-capital-efficiency-market-valueempirical-study-from-iranian-pharmaceuticalcompanies>, [Accessed June 9, 2013].

23. NASDAQ OMX Baltic (2013). Internet access: $<$ http://www.nasdaqomxbaltic.com $>$, [Accessed May 1, 2013].

24. Pulic, A. (2000). VAIC - An Accounting Tool for IC Management // International Journal of Technology Management. Vol. 20, Issue 5, p. 702-714. doi: 10.1504/IJTM.2000.002891.

25. Riahi-Belkaoui, A. (2003). Intellectual Capital and Firm Performance of US Multinational Firms: Study of the Resource-based and Stakeholder Views // Journal of Intellectual Capital. Vol. 4, No. 2, p. 215-226. doi: $10.1108 / 14691930310472839$. 
26. Ryan, B. (2007). Corporate Finance and Valuation - Thomson Learning.

27. Sharma, A. K., Kumar, S. (2010). Economic Value Added (EVA) - Literature Review and Relevant Issues // International Journal of Economics and Finance. Vol. 2, Issue 2, p. 200-220. Internet access: <http://www.ccsenet.org/journal/index. php/ijef/article/view/5908>, [Accessed June 9, 2013].

28. Shiu, H. (2006). The Application of the Value Added Intellectual Coefficient to Measure Corporate Performance: Evidence from Technological Firms // International Journal of Management. Vol. 23, No. 2, p. 356-365. Internet access: <http://connection.ebscohost.com/c/ articles/21276405/application-value-addedintellectual-coefficient-measure-corporateperformance-evidence-from-technologicalfirms $>$, [Accessed June 9, 2013].

29. Stahle, P., Stahle, S., Aho, S. (2011). Value Added Intellectual Coefficient (VAIC): A Critical analysis // Journal of Intellectual Capital. Vol. 12, Issue 4, p. 531-551. doi: 10.1108/14691931111181715.

30. Tawy, N., Tollington, T. (2012). Intellectual Capital: Literature Review // International Journal of Learning and Intellectual Capital. Vol. 9, No. 3, p. 241-259. doi: 10.1504/IJLIC.2012.047286.

31. Tobin, J. (1969). A General Equilibrium Approach to Monetary Theory // Journal of Money,
Credit and Banking. Vol. 1, No. 1, p. 15-29. doi: 10.2307/1991374.

32. Tseng, C., Yeong-Jia, J. G. (2005). Intellectual capital and corporate value in an emerging economy: empirical study of Taiwanese manufacturers // R\&D Management. Vol. 35, Issue 2, p. 187 201. doi: 10.1111/j.1467-9310.2005.00382.x.

33. Volkov, A. (2012). Value Added Intellectual Coefficient (VAIC): A Selective Thematic - Bibliography // Journal of New Business Ideas \& Trends. Vol.10, Issue 1, p. 14-24. Internet access: <http:// www.jnbit.org/upload/JNBIT_Volkov_2012_1. pdf $>$, [Accessed June 9, 2013].

34. Wang, J. (2008). Investigating Market Value and Intellectual Capital for S\&P 500 // Journal of Intellectual Capital. Vol. 9, Issue 4, p. 546-563. doi: $10.1108 / 14691930810913159$.

35. Wang, M. (2013). Value relevance on intellectual capital valuation methods: the role of corporate governance // Quality\& Quantity. Vol. 47, Issue 2, p. 1213-1223. doi: 10/1007/s11135-012-9724-1.

36. Wernerfelt, B., Montgomery, C. A. (1988). Tobin's $q$ and the Importance of Focus in Firm Performance // The American Economic Review. Vol. 78, No. 1, p. 246-250. doi: 10.2307/1814713.

This work has been supported by the European Social Fund within the project „Support for Doctoral Studies at University of Latvia".

The paper submitted: May 15, 2013

Prepared for publication: June 20, 2013

\section{Irina BERZKALNE}

\section{INOVATYVIŲ İMONĖS VERTINIMO METODŲ TAIKYMAS LATVIJOJE: ANALIZĖ IR GERINIMO GALIMYBĖS}

\section{S a n t r a u k a}

Vienas iš pagrindinių įmonès vadovo tikslų yra maksimizuoti įmonès vertę. Imonès vertè yra pagrindinis korporatyvinių finansų matas, nepaisant to surasti įmonès vertę nèra paprasta. Visų pirma skirtingos įmonès turètų būti vertinamos skirtingai (pavyzdžiui, viešoji ịstaiga ir privati įmonè, nesèkminga įmonè ir t.t.). Antra, įmonès vertè taip pat priklauso nuo vertinimo tikslo (viena immonè gali turèti kelias vertes, priklausomai nuo vertinimo metodo). Paskutinius du dešimtmečius pastebimas inovacijų srauto padidejimas finansų rinkose, ta- čiau korporatyvinio vertinimo metodai reikšmingai nepasikeitè. Tradiciniai korporatyvinio vertinimo metodai apima diskontuotų pinigų srautų vertinimą, likvidavimo ir apskaitos vertinimą, santykinị vertinimą ir kontingentinių reikalavimų vertinimą (skirtingi autoriai siūlo įvairias vertinimo metodų grupes). Didžiąją dalị šių metodų nulèmė ankstesnès veiklos rezultatai, tačiau būtina atsižvelgti ị vertę, kurios nèra balanse, tačiau ji yra ir gali didèti.

Tradiciniai korporatyvinio vertinimo metodai yra pagrịsti ịmonès balansu, pajamų ar pinigų 
srautų ataskaitos informacija; tačiau intelektinis kapitalas (IK) taip pat yra turtas. Tačiau balanse jis vertinamas nuliu. Egzistuoja dideli skirtumai tarp imonès vertès rinkoje ir buhalterinès vertès, dalis šių skirtumų gali būti paaiškinti IK. Net jei nèra universalaus IK apibrėžimo, jo informacija numato imonès ateities potencialą.

Tyrimo tikslas - ištirti tradicinius įmonès vertinimo metodus, kaip vertès elementą įtraukiant intelektinị koeficientą (pridètinès vertès intelektinis koeficientas - VAIC ${ }^{\mathrm{TM}}$ ), îvertinti ryši tarp intelektinio kapitalo ir įmonès vertès bei pateikti rekomendacijas tradicinių korporatyvinio vertinimo metodų gerinimui.

Analizè buvo atliekama 31 Latvijos imoneje (Baltijos šalių vertybinių popierių birža) nuo 2005 iki 2011 m. Atliekant tyrimą buvo naudojami tiek kokybiniai, tiek kiekybiniai tyrimų metodai: monografijų, grafinis metodai, aprašomosios statistikos metodas bei koreliacinè analizè. Tyrimas grindžiamas paskelbtais i̇monès vertinimo metodų ir pridètinès vertès intelektinio koeficiento (VAIC ${ }^{\mathrm{TM}}$ ) dokumentais, taip pat Baltijos šalių vertybinių popierių biržos pateikiama informacija.

Tyrimo metu nustatyta, kad tradiciniai įmonès vertinimo metodai dažniausiai pagrịsti fizinio įmonès turto vertinimu, tuo tarpu žiniomis pagrịstoje ekonomikoje daugiau dèmesio skiriama darbuotojams ir intelektiniam kapitalui. Dèl šios priežasties tradiciniai įmonès vertinimo metodai nebèra tinka- mi, nes atsirado poreikis parengti naujas koncepcijas ir metodologijas.

Plačiai naudojamas IK rodiklis yra pridètinès vertès intelektinis koeficientas $\mathrm{VAIC}^{\mathrm{TM}}$, kuris suteikia galimybę, naudojant šị koeficientą, gerinti imonès vertinimo metodus. Tačiau ankstesnių empirinių tyrimų rezultatai yra nesuderinami. Kai kurių tyrimų rezultatai skelbia apie teigiamą koreliaciją tarp IK ir įmonès vertès, tačiau kitų tyrimų rezultatai nepateikia jokio ryšio. Keliuose tyrimuose buvo pastebėtas ryšys tarp pridètinès vertès intelektinis koeficiento elementų ir i̇monès vertès rinkoje. Minètas tyrimas parodè prieštaringus rezultatus tarp pridètinès vertès intelektinio koeficiento VAIC ${ }^{\mathrm{TM}}$ ir imonès veiklos. Jeigu vienoje imoneje analizuojami $\mathrm{VAIC}^{\mathrm{TM}}$ komponentai, tuomet jokių reikšmingų ryšių nebus su SCE, išskyrus koreliaciją tarp SCE ir VAIC ${ }^{\mathrm{TM}}$ įmonèms antrajame sąraše. Tačiau statistiškai reikšmingos koreliacijos egzistuoja tarp HCE, CEE ir Tobin's Q, ROIC vertès.

Šio straipsnio autorius rekomenduoja kompleksinị tradicinių ịmonès vertinimo metodų derinị su VAIC $^{\mathrm{TM}}$ arba jo komponentais CEE ir HCE, siekiant pagerinti įmonès vertinimo modelị. Toks modelis būtų našesnis ir pasiektų geresnius ịmonès vertinimo rezultatus, nes jis apimtų ne tik istorinę informaciją iš finansinių ataskaitų, bet būtų atsižvelgiama ir i IK. Imonès vertè turi būti sudaryta iš abiejų, tiek ilgalaikio materialaus turto, tiek IK. 